\title{
ISSN:
}

Print - $2277-0755$

Online - 2315 - 7453

(C) FUNAAB 2016

Journal of

Agricultural

Science

and Environment

\section{EFFECTS OF SEASON ON AGRO-MORPHOLOGICAL TRAITS OF SOME MUTANT COWPEA LINES}

\author{
*J. B.O. PORBENI, B.M. OLAOLORUN, O. O. SANSA \\ Department of Plant Breeding and Seed technology, \\ Federal university of Agriculture, Abeokuta. Nigeria.
}

*Corresponding author: porbenijbo@funaab.edu.ng

\begin{abstract}
A field experiment aimed at determination of influence of season on the yield potential of some cowpeas lines was carried out at the Teaching and Research Farm of Federal University of Agriculture, Abeokuta, Nigeria located on Latitude $7012^{\prime} \mathrm{N}$ and longitude $3020^{\prime} \mathrm{E}$ during the late rain season (August- November 2013) and early rain season (April- July, 2014). The experiment was laid out in a randomized complete block design with three replicates. Qualitative and quantitative data such as stem petiole pigmentation, leaf colour, flower form and colour, dry pod colour, seed coat texture, plant height, number of days to flower and first ripe pod, pod length , total number of pods/plant, total number of seeds/plant, 100-seeds weight were taken. Combined analysis of variance to determine line $x$ season interaction, while SASTM 9.1, (2000) version statistical package was used to separate the means, Pearson correlation analysis was used to determine the inter-character relationships among the traits. Major characters causing variation within the population was calculated using Principal component analysis (PCA). Most of the cowpea lines were non-pigmented and papillinaeous, except Rosa -1 and 2 that showed rosaceous flower form. Cowpea lines such as Rosa-2, IF-Br-Y-2 and IB-Cyt.Y had yellow foliage, while the flower colour ranged from solid purple and white to white petal with purple wings. Line $\mathrm{x}$ season interaction revealed a high level of significance for most of the traits studied. Means of the cowpea lines' traits were significantly different from one another. Pod length was highly correlated with number of seed per pod, pod per plant and 100 seed weight $(r=0.63,0.45$ and 0.66$)$ respectively, while plant height had a negative and highly significant correlation with days to flowering $(r=-0.58)$ and days to fruiting $(r=-0.60)$.
\end{abstract}

Keywords: Cowpea, mutants, genetic variability, environmental effect and yield.

\section{INTRODUCTION}

Cowpea, Vigna unguiculata (L). Walp. is an annual grain legume which is normally cultivated as a nutritious and highly palatable food source to man and livestock throughout the tropics and sub- tropics (FAO, 2010). Cowpea is a valuable component of the traditional cropping systems in the semi -arid tropics (Singh et al., 1997) and has been domesticated in Africa for centuries. It is a warm-season crop that can be produced in the semi-arid regions and dry savannas. It can be grown in regions with an average annual rainfall of 2.5 to 8 inches (Cook et al., 2005) and can be better adapted to sandy soils and droughty conditions than soybeans 
(TJAI, 2010). Cowpea is a variable species composed of cultivated, wild perennials and annuals forms. Its growth habit ranges from prostrate, semi- erect, erect to climbing, while the pods are either coiled, round, crescent or linear (Porbeni and Fawole, 2004). Genetic variability via mutation has been found to provide a good source of raw materials for evolution. It provides varied alleles that are have gone through changes in its genetic structures in a population (Gardner et al., 1991). Mutation could occur naturally (spontaneous) or artificially (induced) (Dhanavel et al., 2012). A mutant therefore is an organism that exhibits novel phenotype as a result of a change in its genetic material, while agents that induce mutation are mutagens (Chaudhuri, 2002). Fawole (2000) reported two mutant plants that were unifoliate and nonpetiolate with either ovate or orbicular leaf shape and observed that they were each controlled by single recessive genes, which were nonallelic. Awoleye (2000), Adekola and Oluleye (2007) reported two mutants that possess useful agronomic traits with the following advantage; increased yield, easy harvesting and insect tolerance. They concluded that the mutants with short branches and erect growth habit were mostly determinate in nature which was of advantage for planting at higher density, as this leads to significant yield improvement.

Cowpea has been widely studied and it has been a crop with low productivity due to non-availability of high yielding and stable genotypes, partial/ absence of genetic resistance to insect-pests infestation and diseases infection (Ali et al., 2004; Timko and Singh, 2008). However, there is probability of a change in the lines which have undergone mutation because there would have been a change in some traits that are herita- ble. This study is therefore aimed at evaluating the influence of seasons on the behavior and yield potentials of some mutant lines with its wild type.

\section{MATERIALS AND METHODS}

Seeds of six mutant cowpeas, two cultivated and landraces of cowpea lines were planted at the Teaching and Research Farm of Federal University of Agriculture, Abeokuta, Nigeria located on Latitude $7012^{\prime} \mathrm{N}$ and longitude $3{ }^{0} 20^{\prime} \mathrm{E}$ during the late rain season (August- November, 2013) and early rain season (April- July, 2014). Some important features of the lines used are presented on Table 1. The experiment was laid out in a randomized complete block design with three replicates. Each replicate was $4 \mathrm{~m}$ long with an inter-row and intra-row spacing of $60 \mathrm{~cm}$ and $30 \mathrm{~cm}$ respectively. The distance between each replicate was $1 \mathrm{~m}$. Weeding was done every two weeks while fungicide and insecticide were sprayed at manufacturers recommended rate after weeding to control fungi infection and insect pest infestation respectively. From each replicate, the following quantitative data were collected: Plant height at six weeks $(\mathrm{cm})$, number of days to flower, number of days first ripe pod, pod length $(\mathrm{cm})$, total number of pods/plant (pod productivity), total number of seeds/ plant, 100-seeds weight (g), while the cowpea lines were also score for the following qualitative traits: Stem/ petiole pigmentation, flower form, flower colour, leaf colour, dry pod colour, seed coat texture.

\section{DATA ANALYSIS}

Combined analysis of variance to determine the level(s) of significant effects on lines, seasons and line $\mathrm{x}$ season interaction, while Duncan Multiple Range Test (DMRT) was used to separate their means using the SASTM 9.1, (2009) version statistical package. 
Simple correlation coefficients were ob- analysis while the major characters causing tained to determine the type of association variation within the population calculated that existed between all possible pairs of using Principal component analysis. characters using the Pearson correlation

Table 1: Names and important features of the cowpea lines used.

\begin{tabular}{llllll}
\hline $\begin{array}{l}\text { Name } \\
\text { of Lines }\end{array}$ & Source & $\begin{array}{l}\text { Morphological } \\
\text { Trait } \\
\text { of Interest }\end{array}$ & $\begin{array}{l}\text { Organelle Loca- } \\
\text { tion }\end{array}$ & $\begin{array}{l}\text { Seed } \\
\text { Coat Color }\end{array}$ & Status \\
\hline Rosa-1 & UI & $\begin{array}{l}\text { Yellow leaf } \\
\text { Rosa leaf form) }\end{array}$ & Nuclear & Brown & Mutant \\
IF-BR-Y-2 & UI & Yellow leaf & Nuclear & Brown & Mutant \\
Rosa-2 & UI & Rosa leaf form & Nuclear & Black & Mutant \\
IB-Cyt.Y & UI & Yellow leaf & Cytoplasmic & Red & Mutant \\
Ife Brown & IAR\&T & Green leaf & Nuclear & Brown & Cultivar \\
Ife BPC & UI & Leaf & Nuclear & Brown & Mutant \\
TVu 6198 & IITA & White flower & Nuclear & White & Landrace \\
IF-BR-Cr & UI & Crinkled leaf & Nuclear & Brown & Mutant \\
ITK-277-1 & IITA & Pigmented stem & Nuclear & Black & Landrace \\
Modupe & IART & Green leaf & Nuclear & Brown & Cultivar \\
\hline
\end{tabular}

Legend; IITA = International Institute of Tropical Agriculture, Ibadan. Oyo-State, IAR\&T = Institute of Agricultural Research and Training, Ibadan. Oyo-State, and UI= Department of Crop Protection and Environmental Biology, University of Ibadan.

\section{RESULTS}

The qualitative traits observed in the cowpea lines are presented on Table 2. Rosa-2 and ITK-277-1 were pigmented on the petiole and stem respectively. The flower form of the cowpeas used was Papilionaceous except for Rosa-1 and Rosa-2. The leaf colour ranged from yellow (Rosa-1 and IBCyt.Y), green (Ife BPC, TVu 6198) to dark green (IF-BR-Cr, ITK-277-1). However, IFBR-Y-2 had green with yellow speckles foliage colour (Plate 2). Rosa-2, ITK-277-1 and IB-Cyt.Yshowed purple flower colour while others were white standard petal with purple wing petals.

The analysis of variance table showed that all characters studied were highly significant at $1 \%$ probability level for the two planting seasons except for pod length and number of seeds per pod (Table 3). Line $\mathrm{x}$ season interaction was highly significant for all characters studied, while seasonal effect was significant for all traits except for pod length and number of seeds per pod $(\mathrm{P} \leq 0.05)$.

The mean performance for some agronomic characters of the cowpea mutants and other cowpeas used for the study is presented on Table 4. IB-Cyt.Y recorded the longest number of days from sowing to first flower (60.83 days) while Ife Brown took the least number of days to first flower (40 days). TVu 6198 had the highest mean for plant 
EFFECTS OF SEASON ON AGRO-MORPHOLOGICAL TRAITS OF ...

height $(58.11 \mathrm{~cm})$ while Rosa-1 recorded the lowest $(17.73 \mathrm{~cm})$. IB-Cyt.Y and Modupe recorded the longest (69.17 days) and the shortest (49 days) number of days to fruiting respectively.

The inter-character relationships for agronomic traits studied on cowpea lines for two seasons gave a positive and highly significant correlation between days to flowering and days to fruiting $(\mathrm{r}=0.88)$ as shown on Table 5. Association between pod length and number of seeds per pod, number of pod per plant and 100 seed weight were positive and highly significant $(\mathrm{r}=0.63$, 0.45 and 0.66 respectively). Hundred seed weight had a positive and highly significant correlation with plant height $(r=0.40)$, while plant height gave a negative and highly significant correlation with days to flowering ( $\mathrm{r}$ $=-0.58)$ and days to fruiting $(\mathrm{r}=-0.60)$. Eigen vectors and values of the first three principal component axes (PCA) of characters for ten cowpea lines are explained on Table 6. The character loading for the first axis were plant height, days to flowering, days to fruiting and number of pods per replicate; the second axis are days to flowering, days to fruiting, pod length and number of pods per plant while the third axis was loaded with plant height, days to flowering and number of pods per plant.

Table 2: Qualitative characters observed in the cowpea lines.

\begin{tabular}{|c|c|c|c|c|c|c|}
\hline Line & $\begin{array}{l}\text { Stem/'Petiole } \\
\text { Pigmentation }\end{array}$ & Flower Form & Leaf Colour & $\begin{array}{l}\text { Flower } \\
\text { Colour }\end{array}$ & $\begin{array}{l}\text { Dry } \\
\text { Pod Colour }\end{array}$ & $\begin{array}{l}\text { Seed0Coat } \\
\text { Texture }\end{array}$ \\
\hline Rosa-1 & Absent & Rosaceous & Yellow & WPW & Straw & Rough \\
\hline Rosa-2 & Present & Rosaceous & Dark Green & Purple & Dark brown & Smooth, waxy \\
\hline Ife BPC & Absent & Papilionaceous & Green & WPW & Straw & Rough \\
\hline TVu6198 & Absent & Papilionaceous & Green & White & Straw & Rough \\
\hline IF-BR-Cr & Absent & Papilionaceous & Dark Green & WPW & Straw & Rough \\
\hline IF-BR-Y-2 & Absent & Papilionaceous & $\begin{array}{l}\text { Green0with } \\
\text { yellow speckles }\end{array}$ & WPW & Straw & Rough \\
\hline Ife Brown & Absent & Papilionaceous & Green & WPW & Straw & Rough \\
\hline Modupe & Absent & Papilionaceous & Green & WPW & Straw & Rough \\
\hline ITK-277-1 & Present & Papilionaceous & Dark Green & Purple & Dark Purple & Smooth, waxy \\
\hline IB-Cyt.Y & Absent & Papilionaceous & Yellow & Purple & Straw & Smooth, waxy \\
\hline
\end{tabular}

\section{WPW $=$ White standard petal with purple wings}

Table 3: Combined ANOVA for two planting seasons of some characters studied on the cowpea lines.

\begin{tabular}{lllllllll}
\hline Source & Df & PtHt & DtFl & DtFr & Pdl & Sd-Pd & Pd-Pt & $100 \mathrm{Sd}$ \\
\hline Reps & 2 & 115.43 & 1.80 & 0.35 & 4.83 & 3.47 & 9.82 & 6.38 \\
Lines (L) & 9 & $916.81^{* *}$ & $215.94^{* *}$ & $258.35^{* *}$ & $44.46^{* *}$ & $22.91^{* *}$ & $341.34^{* *}$ & $28.72^{* *}$ \\
Seasons(S) & 1 & $7403.48^{* *}$ & $109.35^{* *}$ & $198.02^{* *}$ & 4.44 & 8.82 & $2898.15^{* *}$ & $149.03^{* *}$ \\
L×S & 9 & $414.15^{* *}$ & $33.28^{* *}$ & $52.13^{* *}$ & $7.91^{*}$ & $6.52^{*}$ & $359.63^{* *}$ & $13.27^{* *}$ \\
Error & 38 & 79.86 & 5.36 & 3.60 & 3.23 & 3.01 & 35.62 & 3.35 \\
CV $(\%)$ & & 22.44 & 4.86 & 3.38 & 13.28 & 19.24 & 41.98 & 12.44 \\
\hline
\end{tabular}

Values with ${ }^{*}$ and ${ }^{* *}$ are significant at $5 \%$ and $1 \%$ probability level respectively.

PtHt: Plant Height (cm), DtFl: Days to flowering, DtFr: Days to fruiting, Pdl: Pod Length (cm), Sd-Pd: Seed per Pod, Pd-Pt: Pod per Plant, 100 Sd: 100 Seed Weight (g). 
Table 4: Mean values of characters studied on ten cowpea lines for two planting seasons.

\begin{tabular}{llllllll}
\hline Line & $\begin{array}{l}\text { PtHt } \\
(\mathbf{c m})\end{array}$ & DtFl & DtFr & Pdl $\mathbf{( c m )}$ & Sd-Pd & Pd-Pt & 100 Sd (g) \\
\hline Rosa-1 & $17.73 \mathrm{e}$ & $50.67 \mathrm{~b}$ & $65.00 \mathrm{~b}$ & $10.19 \mathrm{f}$ & $7.67 \mathrm{de}$ & $12.17 \mathrm{~cd}$ & $10.03 \mathrm{~d}$ \\
Rosa-2 & $44.13 \mathrm{bc}$ & $49.33 \mathrm{~b}$ & $56.17 \mathrm{c}$ & $15.55 \mathrm{~b}$ & $8.50 \mathrm{cde}$ & $13.00 \mathrm{~cd}$ & $15.93 \mathrm{~b}$ \\
Ife BPC & $36.61 \mathrm{c}$ & $49.00 \mathrm{~b}$ & $57.00 \mathrm{c}$ & $12.91 \mathrm{~cd}$ & $10.00 \mathrm{abc}$ & $15.33 \mathrm{bc}$ & $15.22 \mathrm{bc}$ \\
TVu 6198 & $58.11 \mathrm{a}$ & $42.50 \mathrm{~cd}$ & $51.67 \mathrm{~d}$ & $14.53 \mathrm{bc}$ & $9.67 \mathrm{abcd}$ & $23.00 \mathrm{a}$ & $15.91 \mathrm{~b}$ \\
IF-BR-Cr & $36.69 \mathrm{c}$ & $43.83 \mathrm{c}$ & $51.17 \mathrm{de}$ & $12.15 \mathrm{def}$ & $9.17 \mathrm{bcde}$ & $7.50 \mathrm{de}$ & $13.06 \mathrm{c}$ \\
IF-BR-Y-2 & $33.83 \mathrm{~cd}$ & $49.50 \mathrm{~b}$ & $57.00 \mathrm{c}$ & $10.58 \mathrm{ef}$ & $7.17 \mathrm{ef}$ & $7.00 \mathrm{de}$ & $14.82 \mathrm{bc}$ \\
Ife Brown & $55.28 \mathrm{ab}$ & $40.00 \mathrm{~d}$ & $49.67 \mathrm{de}$ & $12.77 \mathrm{cde}$ & $10.00 \mathrm{abc}$ & $21.33 \mathrm{ab}$ & $14.10 \mathrm{bc}$ \\
Modupe & $44.40 \mathrm{bc}$ & $42.00 \mathrm{~cd}$ & $49.00 \mathrm{e}$ & $13.57 \mathrm{bcd}$ & $11.17 \mathrm{ab}$ & $14.17 \mathrm{bcd}$ & $14.35 \mathrm{bc}$ \\
ITK-277-1 & $44.05 \mathrm{bc}$ & $48.83 \mathrm{~b}$ & $55.67 \mathrm{c}$ & $19.76 \mathrm{a}$ & $11.67 \mathrm{a}$ & $26.17 \mathrm{a}$ & $18.52 \mathrm{a}$ \\
IB-Cyt.Y & $25.37 \mathrm{de}$ & $60.83 \mathrm{a}$ & $69.17 \mathrm{a}$ & $13.35 \mathrm{bcd}$ & $5.17 \mathrm{f}$ & $2.50 \mathrm{e}$ & $15.14 \mathrm{bc}$ \\
Mean \pm SD & $39.82 \pm$ & $47.65 \pm$ & $56.15 \pm$ & $13.53 \pm$ & $9.02 \pm$ & $14.22 \pm$ & $14.71 \pm$ \\
& 19.60 & 6.59 & 7.28 & 3.21 & 2.59 & 13.39 & 3.36 \\
\hline
\end{tabular}

Table 5: Inter-character relationship of some agronomic traits studied on ten cowpea lines for two planting seasons.

\begin{tabular}{llllllll}
\hline & PtHt & DtFl & DtFr & Pdl & Sd-Pd & Pd-Pt & 100 Sd \\
\hline PtHt & $-0.58^{* *}$ & & & & & & \\
DtFl & $-0.60^{* *}$ & $0.88^{* *}$ & & & & & \\
DtFr & $-0.30^{*}$ & -0.10 & $-0.26^{*}$ & & & & \\
Pdl & 0.32 & $-0.45^{* *}$ & $-0.53^{* *}$ & $\overline{0} .63^{* *}$ & & & \\
Sd-Pd & 0.22 & -0.22 & $-0.28^{*}$ & $0.45^{* *}$ & $\overline{0} .68^{* *}$ & & \\
Pd-Pt & 0.03 & $-0.31^{*}$ & $0.66^{* *}$ & $0.29^{*}$ & $\overline{0} .06$ & \\
$100 \mathrm{Sd}$ & $0.40^{* *}$ & -0.13 & -0.31 & \\
\hline
\end{tabular}

Values with ${ }^{*}$ and ${ }^{* *}$ are significant at $5 \%$ and $1 \%$ probability level respectively.

Table 6: Eigen values and vectors of the first three principal component analyses of quantitative characters observed from ten cowpea lines for two planting seasons.

\begin{tabular}{llll}
\hline Character & Prin1 & Prin2 & Prin3 \\
\hline PtHt & 0.77 & -0.02 & 0.56 \\
DtFl & -0.32 & 0.40 & 0.50 \\
DtFr & -0.37 & 0.45 & 0.22 \\
Pdl & 0.08 & 0.32 & 0.13 \\
Sd-Pd & 0.10 & 0.05 & -0.19 \\
Pd-Pt & 0.38 & 0.71 & -0.52 \\
100 Sd & 0.06 & 0.20 & 0.25 \\
Eigen Values & 243.82 & 32.80 & 21.77 \\
\% Variance & 80.01 & 10.76 & 7.15 \\
\hline
\end{tabular}

PtHt: Plant Height (cm), DtFl: Days to flowering, DtFr: Days to fruiting, Pdl: Pod Length (cm), Sd-Pd: Seed per Pod, Pd-Pt: Pod per Plant, 100 Sd: 100 Seed Weight (g). 


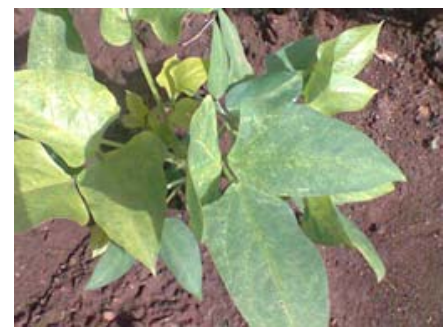

IF-BR-Y-2

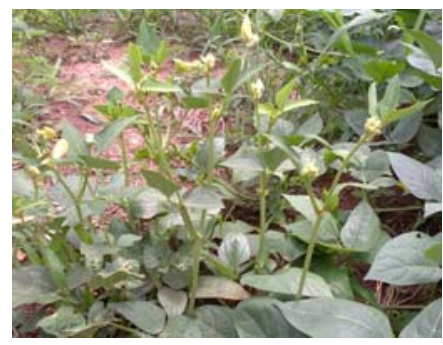

Ife BPC

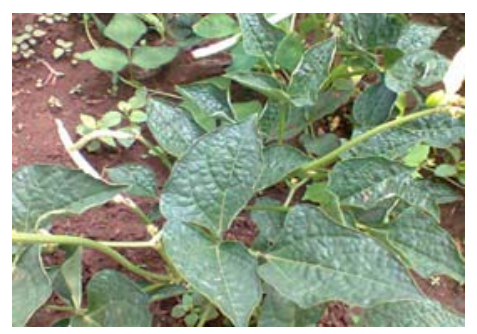

IF-BR-Cr

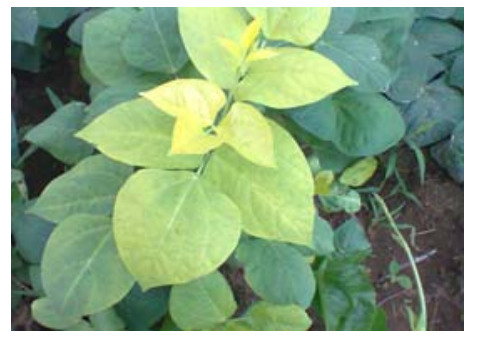

Rosa-1

Plate 1: Morphological features of some of the mutant lines

\section{DISCUSSION}

The main function of chlorophyll during photosynthesis is to absorb radiant energy in form of light from the sun for plant utilization (Nelson, 1967, Porbeni and Fawole, 2012). Changes in the chlorophyll expression can be favorable (green foliage expression) or unfavorable (white or yellow foliage expression). The unfavorable condition is characterized by the presence of the double recessive genes sometimes leading to a lethal mutation (Fawole, 2003; Porbeni and Fawole, 2012; Porbeni and Fawole, 2013). Foliage colour mutation cause changes in the expression of quantitatively inherited agronomic traits such as number of days to flowering, pod and seed traits in cowpea (Porbeni, 2009). The variations observed in the qualitative traits of the cowpea mutant lines could be as a result of their genetic differences. The color and shape of the leaf are very important for photosynthetic activ- ities of a plant. Effect of mutation on any of these can result in positive or negative economic yield effect. Several mutations affecting foliage had been reported in cowpea (Fawole, 1997; Fawole, 2000; Fawole, 2003; Porbeni and Fawole, 2013). The effect of yellow foliage mutation can be seen in the number of days from sowing to first flower and number of seed per pod (IF-BR-Y-2, Rosa-2, and the IB-Cyt.Y mutants). The flower being the reproductive part of the plant is responsible for the production of the major economic portion (seeds) of cowpea. Flower form in cowpea is generally regarded as Papilionaceous with the male and female reproductive parts enclosed by the keel and standard petals, thereby enforcing selfpollination. For mutation affecting flower form (Rose like flower - Rosa) the keel, wing and standard petals are open exposing the male and female reproductive parts. Porbeni (2009) reported that the female part (style) is 
sometimes longer than the stamen, such that when pollens are shed it does not fall on the stigmatic surface for reproduction to take place. The duration between sowing and first ripe pod observed in Rosa-1 could therefore be as result of its rosaeous flower form. These morphological mutant traits are essential for breeders as they could be used as marker gene for selection purpose. The analysis of variance revealed a highly significant variation in all the characters measured during the early and late planting seasons except for pod length and number of seeds per pod. Preeti et al., (2003), Sarvamangala and Cholin (2004) reported similar results in mungbean and cowpea genotypes respectively. Characters with highly significant values will increase the scope of selection for cowpea improvement purposes. Ife-BPC possesses two peduncles which could be better advantage over other lines for yield and related characters. This can be further improved to develop high yielding lines which can be considered during yield trial experiment. The interaction between season and lines indicated that the lines responded differently to seasonal change. This implied that there was variation in phenotypic estimates of characters from one season to another. Therefore, phenotypic expression may not be a true index of genotypic potentials. The result also revealed highly significant difference among the cowpea lines for all characters measured, indicating genetic diversity among the cowpea lines for the characters studied. Similar results were documented by Subramanian and Subbaraman (2010) and Akotkar et al., (2010) for maize and okra respectively. This however, contradicts the report of Moukoumbi et al., (2011) and Akinwale et al., (2011) on mustard seed and Asian rice respectively.

Plant height had a negative but strong cor- relation with days to flowering and fruiting, suggesting that taller plants gets pollinated and produced pods earlier than shorter plants since they had better chances of sunlight absorption. The positive and significant correlation between number of days to flowering and number of days to fruiting suggests that component breeding will be effective and lines that flower early will pod early. This is essential to enhance production in areas with limited environmental resources; that is short period of rainfall [ Hazra and Basu (2000) and Ahiakpa et al., (2012)].

The positive and significant correlation between pod length and number of seeds per pod, number of pods per plant and 100 seed weight will aid selection based on these characters for effective yield improvement [Lesly (2005), Popoola et al,. (2011)].

The scores of the major characters describing the first three factors as revealed by the principal component analysis, confirms the co-variation among the lines studied. The principal component analysis showed that plant height, days to flowering, days to fruiting pod length and number of pods per plant contributed over $90 \%$ variation to the population suggesting that they are the major sources of variation within the mutant lines, and could be considered during selection and in formulating breeding programmes for cowpea improvement. There was an improvement in the yield performance of some mutant lines (IF-BR-Y-2, Ife BPC and IF$\mathrm{BR}-\mathrm{Cr}$ ) over the cultivated varieties. They are therefore recommended for cultivation in different environments due to their desirable agronomic traits and to determine their stability status. 
Adekola, O. F. and Oluleye, F. 2007. Induction of Genetic Variation in Cowpea (Vigna unguiculata L. Walp.) by Gamma Irradiation. Asian Journal of Plant Sciences. 6: 869873.

Ahiakpa, J. K., Amoatey, H. M. and Klu, G. Y. P. 2012. Genetic diversity study: a tool for harnessing okra germplasm in Ghana. Larmbert Academic Publishing. pp 1249.

Akinwale, M. G., Gregorio, G., Nwilene, F., Akinyele, B. O., Ogunbayo, S. A. and Odiyi, A. C.2011. Heritability and correlation coefficient analysis for yield and its components in rice (Oryza sativa L.). African Journal of Plant Science. 5 (3): 207-212.

Akotkar, P.K., De, D.K. and Pal, A. K. 2010. Genetic Variability and Diversity in Okra (Abelmoschus esculentus L.Moench). Electronic Journal of Plant Breeding. 1(4): 393-398.

Ali, Y., Aslam, Z., Hussain, F. and Shakur, A. 2004. Genotype and environmental interaction in cowpea, Vigna unguiculata (L.) Walp. for yield and disease resistance. International Journal of Environmental Science and Technology. 1(2): 119-123.

Awoleye, F. 2000. Mutagenesis in Cowpea: A new plant type, seed coat colour of a local cultivar with improvement in agronomic traits though gamma irradiation. African Science Journal. 1: 49-56.

Chaudhuri, S. K. 2002. A simple and reliable method to detect gamma irradiated lentil (Lensculinaris Medik.) seeds by germination efficiency and seedling growth test. Radiation Physics and Chemistry 64: 131-136.

Cook, B.G., Pengelly, B.C., Brown, S.D., Donnelly, J.L., Eagles, D.A., Franco, M.A., Hanson, J., Mullen, B.F., Partridge, I.J., Peters, M. and Schultze-
Kraft, R. 2005. Tropical forages: an interactive selection tool. Vigna unguiculata. CSIRO, DPI\&F (Qld), CIAT, and ILRI, Brisbane, Australia. pp.14-37.

Dhanavel, D., Gnanamurthy, S. and Girija, M. 2012. Effect of gamma rays on induced chromosomal variation in cowpea. Vigna unguiculata (L.) Walp. International Journal of Current Science. pp. 245-250.

Fawole, I. 1997. Inheritance of crinkled leaf in cowpea, Vigna unguiculata (L.) Walp. Nigerian Journal of Science. 31:35-40.

Fawole, I. 2000. Genetic Analysis of Mutations at Loci Controlling Leaf Form in Cowpea (Vigna unguiculata (L.) Walp.). Journal of Heredity. (92)1:43-50.

Fawole, I. 2003. Genetic characterization of four mutations affecting foliage colour in cowpea, Vigna unguiculata (L.) Walp. Journal of Genetics and Breeding. 58: 371- 378.

Food and Agriculture Organisation (FAO), 2010. The state of food insecurity in the world. United Nations Food and Agriculture Organization, Rome.

Gardner, E. J., Siiumons, M. J. and D. P. Snustad (1991). Principles of Genetics. John Wiley and sons incorporated: New-York. pp. 288-319.

Hazra, P. and Basu, D. 2000. Genetic variability, correlation and path analysis in okra. Annals of Agricultural Research. 21(3): 452-453. Lesly, W. D. 2005. Characterization and evaluation of cowpea (Vigna unguiculata [L.] Walp.)germplasm. M. Sc. (Agric.) Thesis, University of Agricultural Sciences, Dharwad. pp. 111- 112.

Moukoumbi, Y. D., Sie, M., Vodouhe, R., R. Toulou, R., Ogunbayo, S. A. and Ahanchede, A. 2011. Assessing phenotypic 
diversity of interspecific rice varieties using agro-morphological characterization. Journal of Plant Breeding and Crop Science. 3(5): 74-86.

Nelson, O. E. 1967. Biochemical genetics of higher plants. Annual Review of Genetics. 1: 245-265.

Popoola, J. O., Adegbite, A. E. and Obembe, O. O. 2011. Cytological studies on some accessions of African yam bean (AYB) (Sphenostylis stenocastenocarpa Hochst. Ex. A. Rich. Harms). International Research Journal of Plant Science. 2(8):249-253.

Porbeni, J. B. O. 2009. Cytoplasmic and nuclear inheritance of some mutations and their effects on agronomic traits of cowpea. Vigna unguiculata (L). Walp. Ph.D. Thesis. Department of Crop protection and Environmental Biology. University of Ibadan. pp. 118.

Porbeni, J.O and I. Fawole. 2004. Evaluation of some Vigna species for Morphological and Agronomic characteristics. Bulletin of The Science Association of Nigeria. 25: 119- 124.

Porbeni, J. B. and Fawole, I. 2012. Inheritance of yellow foliage colour and instability as a result of transposable element activities in cowpea, Vigna unguiculata (L.) Walp. Journal of Natural Science, Enginering and Technology. 10(2): 67-78.

Porbeni, J. and Fawole, I. 2013. Inheritance of stem fasciation and its effect on some agronomic traits of cowpea. Journal of Crop Science. 53:1937-1943.

Preeti, V., Garg, D. K. and Varma, P.
2003. Estimation of genetic parameters among set of mungbean (Vigna radiata (L.) Wilczek) genotypes. Annals of Agricultural Research. 24(1):156-158.

Sarvamangala, and Cholin, S. 2004. Genetic studies on different plant types of cowpea (Vigna unguiculata (L.) Walp.). M. Sc. (Agric.) Thesis, University of Agricultural Sciences, Dharwad. pp. 86-88

SAS, Statistical Analysis Systems Institute 2009. SAS user's guide, version 9.1. SAS Institute. Inc., Raleigh, North Carolina, USA.

Singh, B. B, Chambliss, O. L, Sharma, B 1997. Recent advances in cowpea breeding. In: Advances in cowpea research (Eds) Singh, B. B., Mohan Raj, D. R., Dashiell, K. E., and Jackai, L. E .N.). Co-publication of International Institute of Tropical Agriculture (IITA) and Japan International Research Center for Agricultural Sciences (JIRCAS) IITA, Ibadan, Nigeria. pp. 30-49.

Subramanian, A. and Subbaraman, N. 2010. Hierarchical cluster analysis of genetic diversity in Maize germplasm. Electronic Journal of Plant Breeding. 1(4): 431-436.

Thomas Jefferson Agricultural Institute (TJAI), 2010. Cowpea: a versatile legume for hot, dryconditions. Columbia, MO. http:// www.jeffersoninstitute.org/pubs/compeas.

Timko, M.P. and Singh, B.B. 2008. Cowpea, a multifunctional legume, In: Genomics of tropical crop plants. Moore, P.H., Ming, R. (Eds.). Springer, New York, pp. 227-257.

(Manuscript received: 24th February, 2016; accepted: 14th June, 2016 